\title{
'N TEOLOGIES-DOGMATIESE BEOORDELING VAN DIE SUID-AFRIKAANSE GRONDWETLIKE KONSEP VAN MENSWAARDIGHEID
}

\author{
N. Vorster ${ }^{1}$
}

\section{ABSTRACT \\ A THEOLOGICAL PERSPECTIVE ON THE SOUTH AFRICAN CONSTITUTIONAL CONCEPT OF HUMAN DIGNITY}

Human dignity is the key foundational value of the South African Constitution. As constitutional value it informs constitutional interpretation at a range of levels. It is therefore important that the concept should be given a concrete content that is juridically applicable. This article examines the ethical content that courts are giving to human dignity and compares it with a reformed biblical view of human dignity. It concludes that the courts are mainly relying on the classical-liberal notion of dignity as an inherent inalienable characteristic of man to define human dignity. The main problem with the classical-liberal concept is that it is an abstract notion which is not based on empirical evidence. This makes it difficult to concretise the concept. It also overemphasises individual rights at the expense of social responsibility, which complicates the balancing of individual and social rights and leads to moral degeneration. The Reformed Christian view defines human dignity as a relational concept and not an inherent possession. It closely links right and responsibility, as well as individual and social rights. Although the Christian concept of human dignity is not juridically applicable in all of its dimensions it can help to contextualise and broaden the concept of human dignity within a South African context.

\section{ALGEMENE ORIËNTERING}

Menswaardigheid is tans 'n kernbegrip binne die Afrika-konteks. Die konsep "Afrika Renaissance" wat deur President Mbeki ontwikkel is en waarop die inisiatiewe van NEPAD en die Afrika-Unie gebou is, het as grondslag die soeke na die herstel van die menswaardigheid van Afrikane na dekades van koloniale onderdrukking, burgerlike oorloë en ekonomiese verval. Volgens Burger (1998:41) spruit die idee van

1 Dr. N. Vorster, Skool vir Kerkwetenskappe, Noordwes-universiteit, Potchefstroomkampus, Potchefstroom. E-pos: nvorster@telkomsa.net. 
'n Afrika Renaissance voort uit die behoefte aan 'n herstel van trots. Dekades van koloniale oorheersing het tot 'n minderwaardige selfbeskouing by baie Afrikane gelei. Volgens die Afrika Renaissance konsep kan menswaardigheid herstel word deur' $n$ terugkeer na die wortels en tradisies van die Afrika-kultuur en 'n ekonomiese herlewing wat Afrika in staat sal stel om dominasie deur die Weste af te skud.

Behalwe vir die breër Afrika-konteks, is menswaardigheid spesifiek binne die Suid-Afrikaanse staatkundige milieu van kernbelang. Een van die kerndoelstellings van die Suid-Afrikaanse Grondwet is om ' $n$ soewereine demokratiese staat te skep wat gefundeer is op menswaardigheid (vgl. art. 1[a]). Hierdie strewe moet in die lig van Suid-Afrika se verlede verstaan word. Die Suid-Afrikaanse Grondwet kan as 'n nooit weer nie Grondwet beskryf word, aangesien die Grondwet geïnterpreteer word teen die agtergrond van Suid-Afrika se verlede van diskriminasie en onderdrukking. Die Grondwet probeer om 'n nuwe samelewing te skep wat in teenstelling met die vorige politieke bedeling die waardigheid van elke individu bevorder en beskerm. Die nooit weer nie motief kan duidelik gesien word in die aanhef tot die 1996-Grondwet. Die aanhef begin deur die "ongeregtighede van die verlede" te erken. Daarna word dit as die doel van die nuwe Grondwet gestel om:

die verdeeldheid van die verlede te heel en 'n samelewing gegrond op demokratiese waardes, maatskaplike geregtigheid en basiese menseregte te skep (aanhef:1996-Grondwet).

Aangesien die herstel van menswaardigheid ' $n$ kerndoelstelling van die nuwe Grondwet is, mag menswaardigheid nie net 'n abstrakte grondwetlike ideaal wees nie, maar moet dit op 'n juridies relevante wyse gekonkretiseer kan word. Die vraag is: Watter konkrete inhoud moet aan menswaardigheid gegee word? Watter bydrae kan die Christelike perspektief op menswaardigheid bied om die samelewing se begrip van menswaardigheid te verryk en te verbreed? In hierdie artikel sal die Suid-Afrikaanse grondwetlike konsep van menswaardigheid vergelyk word met 'n Bybelse perspektief op menswaardigheid. Die sentrale teoretiese argument van die artikel is dat 'n Christelike perspektief op menswaardigheid 'n belangrike bydrae kan lewer om die grondwetlike waarde van menswaardigheid te kontekstualiseer en te verbreed binne die Suid-Afrikaanse konteks. 


\section{MENSWAARDIGHEID IN DIE SUID-AFRIKAANSE GRONDWET}

\subsection{Internasionale ontwikkelings}

Menswaardigheid word wêreldwyd as die kernwaarde in grondwetlike jurisprudensie beskou. Internasionale dokumente gee oor die algemeen 'n wyer inhoud aan menswaardigheid as nasionale dokumente (Ntoubandi 2000:4). Die drie vernaamste internasionale verklarings van menseregte naamlik die Universal Declaration of Human Rights (1948), die International Covenant on Social, Economic and Cultural Rights (1966) en die International Covenant on Civil and Political Rights (1966) verwys almal na menswaardigheid as kernwaarde. Die aanhef van die Universal Declaration of Human Rights beskryf die inherente waardigheid en die gelyke en onvervreembare regte van alle mense as die grondslag vir vryheid, geregtigheid en vrede in die wêreld. Artikel 1 begrond menswaardigheid verder daarin dat alle mense vry en gelyk gebore word met redelike vermoëns en 'n morele gewete. Hieruit blyk dit dat die Deklarasie menswaardigheid as die bron van alle ander regte beskou en dat dit in navolging van die Verligting menswaardigheid in die redelike kapasiteit van die mens fundeer.

In die aanheffings van beide die International Covenant on Social, Economic and Cultural Rights (1966) en die International Covenant on Civil and Political Rights (1966) word menswaardigheid weer eens omskryf as die waarde van waaruit alle ander regte ontleen word. Volgens Cohen (2001:49) kan twee belangrike waarnemings op grond hiervan gemaak word. Eerstens word menswaardigheid as fondament gesien van regte wat beide individuele en kollektiewe belange dien. Tweedens is menswaardigheid fundamenteel nie net vir burgerlike en politieke regte nie, maar ook vir sosiale en ekonomiese regte.

\subsection{Menswaardigheid as kernwaarde van die Suid-Afrikaanse grondwet}

Die Suid-Afrikaanse Grondwet vind aansluiting by internasionale ontwikkelings. In die 1996-Grondwet word verskeie grondliggende bepalings gevind wat spesifieke grondwetlike waardes tot sleutelwaardes 
verhoog (vgl. Venter 2000:1). Hierdie grondwetlike waardes moet van die omskrewe fundamentele regte in die Grondwet onderskei word. Fundamentele regte is subjektiewe afdwingbare en gekonkretiseerde regte wat in die Grondwet omskryf word. Grondwetlike waardes onderlê die fundamentele regte en verskaf fundamentele riglyne vir die interpretasie en toepassing van die Grondwet (Venter 2000:6).

In State v. Makwanyane is die waardegedrewe aard van grondwetlike regspraak telkens beklemtoon. Die Grondwet word nie meer positivisties geïnterpreteer in terme van die oorspronklike bedoeling van die grondwetskrywers nie, maar dit word in die lig van eietydse omstandighede en die grondwaardes van die Grondwet geïnterpreteer sodat 'n oop en demokratiese samelewing geskep kan word (vgl. O'Regan, State v. Makwanyane [322, 323], Du Plessis 1997:14). Die doel van grondwetlike regspraak is om 'n gemeenskaplike waardesisteem te skep wat deur al die inwoners van die land gedeel kan word. Volgens regters Mokgoro en Sachs is dit daarom belangrik dat howe inheemse waardesisteme raadpleeg wat kan help om 'n inklusiewe regspraak te ontwikkel (vgl. State v. Makwanyane par. 302, 304, 361, 362). Dit beteken egter nie dat howe hulleself moet laat lei deur wisselende openbare mening nie. Die waardes en omskrewe regte in die Grondwet self en internasionale norme bly die vernaamste leidinggewende beginsels vir grondwetlike regspraak (vgl. Chaskalson, State v. Makwanyane, par. 87, 88).

Artikel 1 van die Suid-Afrikaanse Grondwet verklaar dat die Republiek van Suid-Afrika 'n soewereine demokratiese staat is wat gegrondves is op die volgende waardes:

a) Menswaardigheid, die bereiking van gelykheid en die uitbou van mensregte en vryhede.

b) Nie-rassigheid en nie-seksisme.

c) Die oppergesag van die Grondwet en die heerskappy van die reg.

d) Algemene stemreg vir volwassenes, 'n nasionale gemeenskaplike kieserslys, gereelde verkiesings en 'n veel-partystelsel van demokratiese regering, om verantwoordingspligtigheid, 'n responsiewe ingesteldheid, en openheid te verseker.

In verskeie artikels word weer spesifiek terugverwys na menswaardigheid, gelykheid en vryheid as basiese waardes van die Grondwet 
(vgl. art. 7[1], 39[1], 143[2]). Die waardes van nie-rassigheid, nieseksisme, die oppergesag van die Grondwet, die heerskappy van die reg, en demokrasie wat ook in artikel 1 genoem word, is almal afgelei van menswaardigheid, gelykheid en vryheid (Venter 2000:4).

Die grondwaardes van menswaardigheid, gelykheid en vryheid geniet in die Grondwet 'n bepaalde rangorde. Menswaardigheid kan as die kernwaarde van die Suid-Afrikaanse Grondwet beskou word. Dit blyk ondermeer uit die volgorde waarin die Grondwet die grondwaardes telkens noem (vgl. art. 1, 7[1], 36[1] en 39[1]); die feit dat die reg tot menswaardigheid en lewe ongekwalifiseerd in artikels 10 en 11 gestel word; en uitsprake van die Konstitusionele Hof self. Regter Chaskalson stel in State v. Makwanyane die belangrikheid van menswaardigheid soos volg:

The rights to life and dignity are the most important of all human rights, and the source of all other personal rights in Chapter Three. By committing ourselves to a society founded on the recognition of human rights we are required to value those two rights above all others.

In Dawood E another (par. 35) wys Regter O'Regan daarop dat menswaardigheid die kernwaarde van die Grondwet is en dat die hele Grondwet in terme daarvan geïnterpreteer word:

The Constitution asserts dignity to contradict our past in which human dignity for black South Africans was routinely and cruelly denied. It asserts it to inform the future, to invest in our democracy respect for the intrinsic worth of all human beings. Human dignity therefore informs constitutional interpretation at a range of levels. It is a value that informs the interpretation of many, possibly all, other rights.

Hierin sluit die Grondwetlike Hof aan by internasionale menseregtedokumente se siening van menswaardigheid as die oorsprong vir alle ander regte.

Die Interim-grondwet het nie na menswaardigheid as grondwaarde verwys nie, maar net na gelykheid en vryheid. Die 1996-Grondwet gebruik egter menswaardigheid as kernwaarde om die ideologiese konflik tussen die waardes van vryheid en gelykheid te bemiddel. Deur gelykheid en vryheid in die lig van die bevordering van menswaardigheid te interpreteer, kan hierdie twee waardes geprioritiseer word wanneer dit in konflik met mekaar kom (vgl. Du Plessis 1997:13). 
Menswaardigheid gee dus inhoud aan die waardes van gelykheid en vryheid, en word terselfdertyd gebruik om kompeterende regte in balans met mekaar te bring.

\subsection{Die konkrete inhoud van menswaardigheid as grondwetlike waarde}

Menswaardigheid is nie 'n statiese begrip nie, maar evolueer saam met die eise van die samelewing. Daarom moet voortdurend inhoud aan die waarde gegee word (Chaskalson 2000:205). Die vraag is: Watter konkrete inhoud gee die grondwet en die howe aan die grondwetlike waarde van menswaardigheid? Artikel 10 van die 1996-Grondwet beskryf die reg op menswaardigheid soos volg: "Elkeen het ingebore waardigheid en die reg dat daardie waardigheid gerespekteer en beskerm moet word".

Van naderby beskou, lyk dit asof artikel 10 'n waarde-uitspraak bevat. Volgens De Waal (1998:176) sluit artikel 10 aan by die liberale tradisie se siening dat die mens vanweë sy redelike natuur intrinsieke waarde het, en dat menswaardigheid daarom geen ekwivalent het nie. Regter Chaskalson (2000:196) meen dat die verwysing na die intrinsieke waardigheid van die mens daarop dui dat menswaardigheid uit die eienskap van lewe voortvloei, en nie iets is wat deur die staat aan mense geskenk word nie. Venter (2000:5) wys tereg daarop dat onderskei moet word tussen menswaardigheid as 'n waarde en as 'n reg. Menswaardigheid as 'n waarde het 'n pre-juridiese bestaanswyse, terwyl menswaardigheid as reg juridies konkreet afdwingbaar moet wees. Artikel 10 probeer nie die reg tot menswaardigheid beskerm nie, maar wel die reg tot respek en beskerming van waardigheid. Dit is noodsaaklik om tussen menswaardigheid as 'n waarde en 'n reg te onderskei omdat dit twee verskillende juridiese konsepte is (Venter 2000:5). Regter O'Regan (Dawood \& another: par. 35) wys in ooreenstemming hiermee daarop dat menswaardigheid nie net 'n waarde is nie, maar ook 'n reg wat gerespekteer en beskerm moet word. In baie gevalle waar die reg tot menswaardigheid aangetas word, sal die presiese oortreding op 'n skending van 'n spesifieke reg soos liggaamlike integriteit neerkom, sodat artikel 10 gewoonlik op 'n indirekte wyse ter sprake sal kom.

Verskeie omskrewe regte in die Handves van Regte staan direk in verband met die beskerming van die waarde van menswaardigheid. 
Artikel 9 bepaal dat die staat nie onbillik teen iemand mag diskrimineer nie. Verskeie gronde word geïdentifiseer op grond waarvan diskriminasie as onbillik uitgeken kan word. Dit sluit in ras, geslagtelikheid, geslag, swangerskap, huwelikstatus, etniese of sosiale herkoms, kleur, seksuele oriëntasie, ouderdom, gestremdheid, godsdiens, gewete, oortuiging, kultuur, taal en geboorte (art. 9:3). Hierdie gronde het almal te doen met eienskappe wat tot die kern van 'n individu se identiteit hoort. Artikel 11 bepaal dat elkeen 'n reg het op lewe, artikel 12 dat elkeen die reg het om nie op wrede, onmenslike of vernederende wyse behandel of gestraf te word nie; en artikel 13 dat niemand aan slawerny, knegskap of dwangarbeid onderwerp mag word nie.

Die Konstitusionele Hof het in verskeie uitsprake verdere inhoud aan die grondwaarde van menswaardigheid gegee. In State v. Makwanyane het die Hof uitspraak oor die grondwetlikheid van die doodstraf gegee. Rigtinggewende uitsprake oor menswaardigheid en die reg op lewe is gemaak. Die Hof het aangesluit by die klassieke-liberale tradisie se siening dat menswaardigheid die inherente en onvervreembare besit van elke mens is. Volgens Regter Sachs sluit die nuwe Grondwet aan by die Konstitusionalisme wat 'n produk van die Verligting was, en wat gebaseer is op die uitgangspunt dat alle mense inherente regte besit. Regters Chaskalson, Langa, O'Regan, Mokgoro en Sachs het in ooreenstemming hiermee beklemtoon dat menswaardigheid en die reg op lewe onvervreembare regte is wat die basis vir alle ander persoonlike regte vorm (par. 84, 217, 311, 313, 328). Daarom stel die Grondwet die reg op lewe ongekwalifiseerd. Dit is in teenstelling met ander grondwette, soos die Kanadese Grondwet, wat die reg tot lewe en menswaardigheid kwalifiseer met die beginsel van geregtigheid (vgl. Mohamed \& another: par. 52). Die reg op lewe behels nie net lewe op organiese wyse nie, maar ook die reg tot 'n menswaardige bestaan (O'Regan, par. 214). Geen mens kan heeltemal van sy regte ontneem word nie, selfs nie 'n krimineel nie; gevolglik is die doodstraf nie grondwetlik aanvaarbaar nie. Die feit dat die mens se regte onvervreembaar is beteken egter nie dat dit nie ingeperk kan word nie. Tog mag die essensie van 'n reg nooit vernietig word nie omdat regte onvervreembaar is. Die doodstraf vernietig lewe en is daarom 'n ontkenning van die individu se onvervreembare reg tot menswaardigheid (par. 217-218). Die Hof het verder beklemtoon dat die toepassing van die doodstraf 
menswaardigheid skend omdat dit in terme van artikel 11.2 op wrede, onmenslike en degraderende straf neerkom (par. 199, 314).

Verskeie regters het in State v. Makwanyane menswaardigheid aan die beginsel van ubuntu verbind. Die Interim-Grondwet het eksplisiet na ubuntu verwys sonder om die konsep te verklaar, terwyl die finale Grondwet glad nie na ubuntu verwys het nie. Volgens Regters Langa, Madala, Mahomed en Mokgoro gee ubuntu inhoud aan menswaardigheid (par. 224, 237, 263, 307). Regter Langa meen dat ubuntu klem lê op die kommunaliteit en interafhanklikheid van die gemeenskap waarin die regte en die pligte van die individu korreleer met die regte en pligte van die gemeenskap (par. 224). Soos die klassieke-liberalisme verstaan ubuntu menswaardigheid as die inherente besit van die mens (par. 227). Regter Madala (par. 237) bring ubuntu veral in verband met rehabilitasie. Ubuntu dui op "humaneness, social justice and fairness". Dit onderlê die Grondwet en spesifiek die Handves van Regte. Om geen ruimte vir rehabilitasie te laat nie, is in stryd met ubuntu, want ubuntu roep die staat op tot medelye. Die belange van die staat en die individu moet gebalanseer word en die individu mag nooit gedehumaniseer word nie (par. 250). Regter Mahomed wys daarop dat ubuntu die inherente menswaardigheid van die mens, maar ook die wederkerige en kollektiewe aard van menswaardigheid beklemtoon (par. 263), terwyl regter Mokgoro ubuntu beskryf as 'n gemeenskaplike waarde wat in al die kulture van Suid-Afrika voorkom. Ubuntu omskryf sleutelwaardes soos groepsolidariteit, mededoë, respek, menswaardigheid, kollektiewe eenheid en konformering aan basiese norme (par. 307, 308). Uit die bogenoemde blyk dit dat die Konstitusionele Hof $u b u n t u$ wou gebruik om benewens die individuele komponent ook 'n kollektiewe inkleding aan menswaardigheid te gee. Die hele gemeenskap staan hiervolgens in 'n interafhanklike verhouding van die erkenning van regte en die uitoefening van pligte (vgl. Vorster 2003:256). Die toepassing van die doodstraf skend nie alleen die waardigheid van die individu nie, maar die waardigheid van die gemeenskap as geheel (vgl. Schooling 1999:12).

Sedert State v Makwanyane het die Konstitusionele Hof nie weer die $u$ buntu-beginsel gebruik of verdere inkleding daaraan probeer gee nie. Volgens Kroeze $(2002: 260,261)$ het die howe se formalistiese definisie van ubuntu in State v. Makwanyane dit onmoontlik gemaak om die konsep verder te gebruik. Sy noem drie redes: In die eerste plek 
het die Hof ubuntu probeer aantoon as 'n plaaslike verskynsel van 'n universele fenomeen. Die gevolg is dat die konsep sy uniekheid en bruikbaarheid verloor het. Tweedens het die Konstitusionele Hof se definisies van ubuntu neergekom op die formulering van groot en leë konsepte wat juridies moeilik gekontekstualiseer kan word. Derdens het die Hof in 'n digotomie tussen individualisme en kommunitarisme begin verval.

Aangesien menswaardigheid en die reg op lewe onvervreembare regte is, het die Hof in ander uitsprake bevind dat die staat positiewe stappe moet neem om menswaardigheid en die reg op lewe te beskerm. In Mohamed $E$ another het die Hof bevind dat aangeklaagdes nie aan ander lande uitgelewer mag word as daar 'n kans bestaan dat so 'n persoon die doodstraf kan ontvang nie. In Carmichele v. Minister of Safety and Security (par. 44, 45) het die Grondwetlike Hof benadruk dat die gemenereg positief deur howe ontwikkel moet word om landsburgers se reg tot menswaardigheid en lewe positief te beskerm. So mag verdagte geweldsmisdadigers nie sondermeer op borgtog vrygelaat word nie.

In die saak van die Christian Lawyers Association of South Africav. Minister of Health is verder belangrike uitsprake oor die reg op lewe gemaak wat tot die essensie van menswaardigheid hoort. Die Christian Lawyers Association het die grondwetlikheid van die Wet oor die Keuse van Beëindiging van Swangerskap voor die Transvaalse Hooggeregshof bevraagteken op grond van artikel 11 wat bepaal dat elkeen die reg op lewe het. Volgens die Christian Lawyers Association is hierdie reg ook op 'n ongeborene van toepassing. Regter McCreath het die klag egter verwerp. Volgens hom verwys die term "elkeen" in artikel 11 na alle persone wat regte dra en nie na 'n nuwe klas van regsubjekte nie. Hy ontken nie noodwendig die lewende status van 'n fetus nie. Die vraag is egter of ' $n$ fetus dieselfde wetlike status as 'n regsdraende persoon kan kry (par. 1348, J). Volgens McCreath gee die Grondwet nêrens aan die fetus 'n juridiese status nie, en word die fetus nêrens beskerm afhangende van die vervulling van die nasciturus reël nie. As die Grondwet die regte van die fetus sou wou beskerm, sou dit in artikel 28 by die regte van kinders ter sprake gekom het. Die vrou se regte word ook nêrens gekwalifiseer om plek te maak vir die regte van 'n fetus nie, terwyl dit moeilik is om te sien hoe grondwetlike regte soos vryheid van spraak op 'n fetus van toepassing gemaak kan word (par. 
$1348, \mathrm{~F}-\mathrm{I})$. Indien die reg van die fetus beskerm sou word, sou dit in konflik kom met verskeie regte van die vrou wat grondwetlik beskerm word (par. 1443 E-G). Die etiese implikasies van die uitspraak is tweërlei: Eerstens hang menswaardigheid en organiese lewe nie in alle gevalle noodwendig saam nie. Menswaardigheid hang af van die mens se vermoë om op grondwetlike regte aanspraak te maak. Dit veronderstel redelike vermoëns en 'n selfstandige bestaan. Tweedens hang menswaardigheid ten nouste saam met persoonlike outonomie en vryheid van keuse, aangesien die vrou se reg op haar liggaam en beheer oor reproduksie klaarblyklik swaarder weeg as 'n organisme se reg op lewe.

Menswaardigheid word verder deur die Konstitusionele Hof gebruik as 'n juridiese kriterium wat gelykheid onderlê. In Prinsloo v. Van der Linde (par. 32) begrond die Hof gelykheid in die inherente gelykwaardigheid van elke mens. Die doel van gelykheidsjurisprudensie is om te keer dat individue of groepe tot minderwaardigheid verlaag word en om te verseker dat alle burgers hulleself kan realiseer sonder om gemarginaliseer te word (National Coalition for Gay and Lesbian Equality v. Minister of Justice par. 129, 36). In dieselfde uitspraak stel Regter Sachs dat gelykheid en menswaardigheid as komplementerende waardes gesien moet word. Ongelyke behandeling lei tot die aantasting van menswaardigheid, terwyl die aantasting van menswaardigheid weer tot ongelykheid kan lei. Deur die waarde van menswaardigheid nou aan gelykheid te verbind, kan die howe, volgens Sachs, groter klem lê op konteks, die impak van optrede en die sienswyse van die geaffekteerde persoon. Op hierdie wyse word 'n situasie-sensitiewe benadering bevorder, abstraksie vermy, en substantiewe gelykheid bevorder (par. 125-126).

Volgens Cohen (2001:36) is menswaardigheid veral in drie opsigte van deurslaggewende belang vir gelykheidsjurisprudensie. Eerstens word die waarde van menswaardigheid gebruik om te bepaal of diskriminasie plaasvind op 'n grond wat nie in die nie-diskriminasieklousule van die grondwet omskryf word nie (vgl. art. 9[3]). In Prinsloo v. Van der Linde $\mathcal{E}$ another word diskriminasie gedefinieer as:

... treating human beings in a way which impairs their fundamental human dignity as human beings, who are inherent equal in dignity (par. 31). 
Diskriminasie wat die fundamentele waardigheid van ' $n$ individu aantas, vind plaas wanneer teen 'n persoon gediskrimineer word op grond van ' $n$ inherente persoonlike of fisiese eienskap wat onveranderlik is en waarteen 'n persoon nie kan kies of waaroor hy geen beheer het nie. Hierin sluit die regters aan by die Kantiaanse siening van menswaardigheid waarvolgens elke mens die intrinsieke reg het om nie as 'n instrument of objek vir ander behandel te word nie. Dit gebeur wanneer persone geobjektiveer word op grond van persoonlike eienskappe (par. 31). In State v. Dodo stel regter Ackermann dit soos volg:

Human beings are not commodities to which a prize can be attached, they are creatures with inherent and infinite worth, they ought to be treated as ends in themselves, never merely as means to an end (par. 38).

In President of the Republic of South Africav. Hugo het die howe laat blyk dat dit nie net oor onveranderlike eienskappe gaan nie. Dit sluit ook karakteristieke in wat tot die kern van die individu se identiteit hoort, soos geslag en seksuele voorkeur wat nie noodwendig biologies vasgestel is nie, maar 'n vorm van 'n sosiale konstruksie kan wees. Tot die kern van menswaardigheid hoort die reg van die individu om sy eie identiteit vrylik te kan kies (par. 80).

Tweedens word menswaardigheid gebruik om te bepaal of die vorm van diskriminasie regverdig of onregverdig is. Die toets vir die regverdigbaarheid van 'n spesifieke vorm van diskriminasie fokus op die impak van die diskriminasie op die klaer, sy posisie in die samelewing, sy blootstelling aan vorige patrone van historiese onderdrukking, die aard van die diskriminasie en die doel wat daarmee bereik wil word. Al hierdie faktore bepaal of die persoon se fundamentele waardigheid deur die betrokke vorm van diskriminasie aangetas is. Derdens word menswaardigheid gebruik om vas te stel of 'n vorm van onregverdige diskriminasie wel onder die beperkingsklousule van artikel 36 geregverdig kan word. Met die inperking van 'n reg word 'n proporsionaliteitstoets toegepas. Hiervolgens moet 'n beperking 'n rasionele band met 'n doelwit hê, die tersake reg moet so min as moontlik ingeperk word, daar moet proporsionaliteit wees tussen die effek van die beperking en sy doel, en die howe moet vasstel of daar 'n alternatiewe maatreël is wat gebruik kan word om die doel van die inperking te bereik (State v. Makwanyane par. 104-106). 
Die tweede en derde stappe impliseer duidelik dat menswaardigheid in die lig van Suid-Afrika se verlede geïnterpreteer word. Menswaardigheid het daarom binne die Suid-Afrikaanse konteks ' $n$ beduidende negatiewe inhoud, omdat die impak van vorige patrone van diskriminasie op mense tot 'n groot mate bepaal wat menswaardigheid is (vgl. Cohen 2001:43). Binne die Suid-Afrikaanse konteks word menswaardigheid gedefinieer deur die basiese vereistes wat nodig is om 'n nuwe, oop en demokratiese samelewing te skep in teenstelling met die verlede. Selfbeskikking vorm byvoorbeeld 'n belangrike komponent van die nuwe samelewing se verstaan van menswaardigheid, juis omdat die vorige politieke bedeling sekere groepe mense van hulle keusevryheid ontneem het.

Menswaardigheid word ook deur die howe ten nouste aan vryheid verbind. In Ferreira v. Levin (49) stel Regter Ackermann dat daar geen sprake van menswaardigheid kan wees sonder vryheid nie:

Human dignity has little value without freedom, for without freedom personal development and fulfilment are not possible. Without freedom, human dignity is little more than abstraction.

Aangesien die mens 'n inherente menswaardigheid besit, besit hy ook ' $n$ inherente individuele outonomie en reg op vrye identiteitsvorming wat veral in artikels 12-14 van die 1996-Grondwet beskerm word. Individuele outonomie gaan altyd gepaard gaan met die erkenning van menslike interafhanklikheid. Daarom kan sekere vryhede soms ingeperk word (Ferreira v. Levin par. 54, 251). Individuele outonomie mag egter nooit op so 'n wyse ingeperk word dat 'n persoon se menswaardigheid daardeur aangetas word nie. Die vryhede omskryf in artikel 12 en 13 beskerm byvoorbeeld liggaamlike integriteit en sluit daarom aspekte van individuele outonomie in wat die essensie van menswaardigheid raak en daarom nie vervreem mag word nie. Ander vryhede wat individuele outonomie beskerm, soos die reg op privaatheid, kan ingeperk word. In die persoonlike sfeer word die reg tot privaatheid byvoorbeeld tot 'n groot mate beskerm, maar die skopus van die reg neem af as die individu die publieke lewe begin betree (Bernstein v. Bester par. 67). 
Artikels $15-22^{2}$ omskryf vryhede wat selfrealisering beskerm. Die Konstitusionele Hof verbind die vryheid tot selfrealisering ten nouste aan menswaardigheid. Deel van die mens se waardigheid is geleë in sy uniekheid as individu en sy reg om sy gawes uit te leef (vgl. Ferreira v. Levin par. 49). Selfrealisering gaan daaroor dat elke persoon die reg het om sy eie identiteit te ontwikkel sonder inmenging van die staat (vgl. Ferreira v. Levin par. 52). Volgens Regter Sachs hang die reg tot selfrealisering ook saam met die beskerming van diversiteit wat 'n belangrike element van menswaardigheid is. Elke individu het die reg om nie gedwing te word om aan godsdienstige en kulturele norme te konformeer nie, om uniek te wees, en van die algemene norm te kan afwyk (Prince v. President par. 170). 'n Persoon se reg tot selfrealisering kan alleen ingeperk word wanneer sy poging tot realisering ' $n$ bedreiging vir die gemeenskap begin word. So het die Hof in Curtis v. Minister of Safety and Security bevind dat geen persoon daarvan weerhou kan word om pornografiese materiaal in sy private besit te hê nie, solank die materiaal nie skade vir die gemeenskap inhou nie (vgl. Par. 27, 37 en 47).

Menswaardigheid word laastens deur die howe aan die realisering van sosio-ekonomiese regte verbind wat in artikels 26, 27 en 28 (1c) beskerm word. Dit sluit in die reg tot grond, behuising, mediese versorging, kos, water, sosiale sekuriteit en die reg tot onderwys. Volgens Regter Chaskalson (2000:2004) is sosiale en ekonomiese regte in die Grondwet gewortel in menswaardigheid. Sonder toegang tot behuising, gesondheidsorg, voedsel of water kan daar geen sprake wees van 'n menswaardige bestaan nie. In sulke gevalle moet egter nie net die belange van individue nie, maar van die gemeenskap as geheel in gedagte gehou word. In Government of the Republic of South A frica v. Grootboom (par. 44) het die Hof gestel dat 'n samelewing nie op menswaardigheid gebou kan word as daar nie aan die basiese lewensbehoeftes van landsburgers voorsien word nie. Die staat moet daarom behuising, mediese versorging, toegang tot kos en water, en gelyke toegang tot grond vir alle landsburgers verskaf (par. 93-94). Die verpligtinge wat

2 Hierdie artikels beskerm vryhede soos vryheid van godsdiens, oortuiging en mening; vryheid van uitdrukking; die reg op vergadering, betoging, linievorming en petisie; vryheid van assosiasie; politieke regte; burgerskap; vryheid van beweging en verblyf; en vryheid van bedryf, beroep en professie, wat ten nouste met selfrealisering saamhang. 
op die staat gelê word is egter afhanklik van beskikbare bronne. Die reg tot sosio-ekonomiese regte kan ingeperk word as gevolg van 'n gebrek aan beskikbare bronne (Minister of Health $\mathcal{E}$ another $v$. Treatment Action Campaign par. 31). Die taak van die staat ten opsigte van sosio-ekonomiese het drie sleutelelemente (par. 21). Die staat is verplig om redelike wetlike en ander maatreëls te tref (1), binne sy beskikbare bronne (2) om die progressiewe realisering van sosio-ekonomiese regte te bereik (3). Volgens Cohen (2001:53) is die grondwetlike waarde van menswaardigheid nie net ' $n$ instrument om individuele en kollektiewe belange te beskerm nie, maar kan dit ook gebruik word om staatsinmenging ten opsigte van ekonomiese ontwikkeling te regverdig.

Samevattend kan die volgende beginsels geïdentifiseer word as kerninhoud van die Suid-Afrikaanse grondwetlike regspraak se konsep van menswaardigheid:

- Menswaardigheid is 'n inherente eienskap van die mens wat aan menswees ontleen word, en nie deur die staat aan die mens geskenk word nie. Dit is die bron vir alle ander regte en daarom onvervreembaar.

- Onveranderlike eienskappe van die mens, soos geslag en ras, asook ander persoonlike eienskappe wat tot die kern van menslike identiteit hoort, soos godsdiens, staan in 'n direkte verband met menswaardigheid. Sodra teen iemand op hierdie gronde gediskrimineer word, kom sy menswaardigheid in gedrang. Die mens het die reg om nie geobjektiveer te word as 'n middel tot 'n doel nie, maar wel om as 'n doel opsigself behandel te word.

- Die Grondwetlike Hof het aanvanklik die ubuntu-konsep gebruik om die inherente menswaardigheid van die mens, maar ook die wederkerige en kollektiewe aard van menswaardigheid te beklemtoon. Die belange van die staat en die individu moet gebalanseer word, en die individu mag nooit gedehumaniseer word nie. Hierdie begrip is egter nie weer deur die howe gebruik nie, met die gevolg dat die kollektiewe betekenis van menswaardigheid nog inkleding moet ontvang.

- Menswaardigheid hang af van die mens se vermoë om op grondwetlike regte aanspraak te maak. Dit veronderstel redelike vermoëns en 'n selfstandige bestaan. 
- Gelykheid word in die gelykwaardigheid van alle mense begrond. Die howe gebruik menswaardigheid en gelykheid as komplementerende waardes. Menswaardigheid word verder as juridiese kriterium in gelykheidsjurisprudensie gebruik om te bepaal wanneer diskriminasie onregverdig is. So word 'n situasie-sensitiewe benadering geskep om substantiewe gelykheid te bevorder.

- Menswaardigheid het binne die Suid-Afrikaanse konteks 'n beduidende negatiewe inhoud, omdat dit in die lig van vorige patrone van diskriminasie gekonkretiseer word. Die basiese vereistes wat nodig is om 'n oop en demokratiese samelewing te skep, definieer tot 'n groot mate menswaardigheid.

- Daar bestaan 'n noue verband tussen menswaardigheid en vryheid. Aangesien die mens ' $n$ inherente menswaardigheid besit, besit hy ook ' $n$ inherente individuele outonomie, reg op vrye identiteitsvorming en reg tot selfrealisering.

- Menswaardigheid hang ten nouste saam met die reg tot toegang tot basiese hulpbronne. Daar is daarom 'n noue verband tussen die realisering van sosio-ekonomiese regte en menswaardigheid.

Uit die bogenoemde word dit duidelik dat die howe grootliks by die klassiek liberale mensbeskouing aansluit wat regte in die inherente eienskappe van die mens fundeer. Aangesien die regspraak egter self erken dat dit poog om 'n inklusiewe gemeenskaplike waardesisteem te skep, behoort die regsgemeenskap ook kennis te neem van ander mensbeskouings wat algemeen in die Suid-Afrikaanse samelewing gehuldig word. In die lig hiervan word vervolgens 'n reformatories-Christelike perspektief op menswaardigheid gebied.

\section{3. 'N REFORMATORIESE PERSPEKTIEF OP MENSWAARDIGHEID}

\subsection{Hermeneutiese uitgangspunte}

Die konsep van menswaardigheid het 'n nie-Christelike oorsprong. Die Stoïsyne het die begrip eerste gebruik. In die Middeleeue is dit deur Christene oorgeneem en in die Renaissance is dit weer humanisties geherinterpreteer (Ryke 2000:379). Hoewel die begrip menswaardig- 
heid in die na-Bybelse tyd ontstaan het, behoort die saak van menswaardigheid tot die kern van die Bybelse boodskap. Die vraag is: Watter hermeneutiese reëls kan gebruik word om 'n verantwoordelike teologiese beskouing oor menswaardigheid te formuleer?

In die interpretasie van die Skrif is dit noodsaaklik dat die skopus en rigpunt van die Skrif verreken word. Die Skrif handel oor die verhouding tussen God, mens en aarde. Uit die interaksie tussen God en mens op aarde ontwikkel 'n aantal deurlopende temas wat die boodskap van die Skrif vorm en wat op Christus uitloop (König 2002:29). Menswaardigheid behoort daarom in die lig van die ontwikkelingslyn of reliëf van die Skrif bestudeer te word. Deur van die reliëf van die Skrif te praat, word die inhoud van die Skrif nie gereduseer tot ' $n$ bepaalde kerninhoud nie, maar word die sentrale gerigtheid van die Skrif in sy verskeidenheid beklemtoon. Alles in die Skrif lê nie op dieselfde vlak nie. Daar is dinge wat oorheers en in die sentrum staan en daar is lyne of trajekte wat die sentrum gaandeweg sterker belig en verduidelik (König 2002:92). Sommige uitsprake in die Bybel is op 'n spesifieke situasie afgestem, terwyl ander uitsprake 'n universele strekking het. Die vraag is: Watter maatstawwe behoort te geld vir die onderskeid tussen kerntemas wat die sentrum van die geloof raak en sake wat nie die sentrum rak nie? König (2002:50) noem vier maatstawwe wat met vrug gebruik kan word:

- Die saak moet herhaaldelik in die Skrif voorkom.

- Dit moet in verskillende verbande in die Skrif voorkom.

- Die Skrif moet daaraan spesifieke teologiese betekenis gee.

- Dit moet uiteindelik op een of ander manier met Christus in verband staan.

Die Skrif bevat verskeie sulke sentrale temas wat aan die bogenoemde maatstawwe voldoen. Vir die doeleindes van hierdie artikel sal op die mens se beeldskap van God, sosiale geregtigheid en die verbond, die herskeppende werk van Christus, en die betekenis van die koninkryk gefokus word. Al hierdie temas kom herhaaldelik in verskillende verbande in die Skrif voor en verskaf universele beginsels wat, ondanks verskillende historiese omstandighede, ditself telkens uitlig as deel van die kernboodskap van die Skrif. 


\subsection{Die mens as beeld van God}

Binne die reformatoriese teologie word die waardigheid van die mens hoofsaaklik gefundeer in die mens se beeldskap van God. Die vraag is: Waarop dui die begrip imago Dei? Die mens se beeldskap van God is in die geskiedenis dikwels verstaan as 'n wesens-ontologiese begrip wat op inherente kwaliteite van die mens dui. Binne die Aristoteliaanse tradisie is die mens se beeldskap direk verbind aan sy rasionaliteit, Kant soek die beeldskap in die morele kapasiteit van die mens en Hegel in die wilsvryheid van die mens. Die Rooms-Katolieke en OostersOrtodokse tradisies het weer onderskei tussen die beeld van God in 'n natuurlike en bo-natuurlike sin. Die natuurlike beeldskap dui op die mens se rasionele kapasiteit en die bonatuurlike beeldskap dui op 'n bonatuurlike gelykenis aan God (vgl. Vorster 2003:282, Ramsey 1993:251).

'n Wesens-ontologiese siening van die imago Dei is egter onhoudbaar omdat dit die beeldskap van die mens losmaak van die verhouding tussen God en mens, en die mens verselfstandig teenoor die Een na wie se beeld hy geskape is. Die imago Dei is eerder 'n relasionele begrip wat die mens se geskape status teenoor God, sy medemens en die niemenslike skepping uitdruk. Dit dui daarop dat die mens voor God se aangesig leef, dat hy kan antwoord op God se eise en dat die mens namens God in die wêreld optree.

In Genesis 1:26 word twee stamme vir die mens se beeldskap van

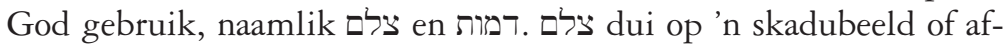
beelding, terwyl דמות op 'n refleksie of kopie dui (vgl. Wentsel 1987: 593). Geen duidelike definieerbare onderskeid bestaan tussen hierdie twee begrippe nie. Dit is sinonieme wat afwisselend van mekaar gebruik word om gemeenskap tussen God en mens uit te druk. Hierdie begrippe het waarskynlik 'n polemiese doel. Enersyds beklemtoon dit dat die mens 'n fisieke verteenwoordiger van God is, maar dat daar geen wesens-eenheid tussen God en mens bestaan nie. Die mens is 'n gelykenisbeeld van God. Andersyds is die begrip 'n fundamentele kritiek teen die vergoddeliking van regeerders. Nie die koning nie, maar die mens is God se verteenwoordiger op aarde (vgl. Moltmann 1984:23). 
Waardigheid is daarom nie ' $n$ inherente status nie, maar dit is ' $n$ status wat God aan die mens toeken deur Homself met die mens te bemoei. Omdat God alle mense na sy beeld skape, is menswaardigheid 'n universele kenmerk van alle mense. Terselfdertyd bevat die mens se beeldskap 'n sterk individuele komponent. Elke mens met sy eie karaktertrekke is as individu verantwoordbaar voor God. Calvyn lê baie klem daarop dat die mens deur sy beeldskap God se deugde in sy eie lewe kan weerspieël (Inst. 1.15.4). In die Nuwe Testament word die beeldskap duidelik in verband gebring met 'n uitstraling van God se heerlikheid in die wyse waarop die mens God verteenwoordig (vgl. 2 Kor. 3:18).

Aangesien die mens se beeldskap dui op die afhanklikheid en die gerigtheid van die mens op God, is menswaardigheid onlosmaaklik verbonde aan die reg van die mens om sy Skepper te kan aanbid. Terselfdertyd veronderstel menswaardigheid 'n fundamentele reg tot lewe. Sonder lewe kan die mens God se beeld nie vertoon nie. Genesis 9:6 verbied doodslag omdat dit die mens se beeldskap van God vernietig. Wanneer 'n mens die lewe van 'n ander neem, speel hyself god, en vernietig hy God se eiendom.

'n Menswaardige bestaan is terselfdertyd 'n opdrag tot die mens. Omdat menswaardigheid 'n status is wat God aan die mens toeken, behoort die mens ooreenkomstig sy status te leef en ander ooreenkomstig hulle status te behandel. Sodra die mens van sy Skepper vervreem raak, word God se beeldskap in die mens verdraai en eien die mens vir hom 'n waardigheid toe wat nie meer op God gerig is nie, maar op homself. Menswaardigheid is dan nie meer 'n status wat God aan die mens toeken nie, maar 'n status wat die mens vir homself opeis. Die gevolg is dat die mens geneig is om selfsugtig regte vir homself op te eis, maar om nie die korrelate verantwoordelikhede wat daarmee gepaard gaan te aanvaar nie.

In Genesis 1:28 word die beskrywing van die mens se geskapenheid na die beeld van God opgevolg deur die oproep om vrugbaar te wees en oor die skepping te heers. Met heers word nie bedoel dat die mens die skepping kan uitbuit nie, maar wel dat die mens in 'n verhouding tot die skepping staan en as God se verteenwoordiger die skepping moet onderhou, regeer en oppas (Gen. 2:15). Deurdat God die mens 
as sy rentmeester roep, ken God aan die mens 'n bepaalde vryheid toe om homself te realiseer. Die reg tot werk is daarom 'n wesentlik deel van die mens se waardigheid. Onmenslike werksomstandighede, armoede, die ontkenning van basiese ekonomiese regte, ekonomiese uitbuiting, die weerhouding van toegang tot natuurlike bronne ensovoorts, is 'n wesentlike aantasting van die mens se beeldskap van God (vgl. Moltmann 1984:27). Sonder die realisering van sosio-ekonomiese regte kan daar geen sprake van 'n menswaardige lewe wees nie. Die mens het die reg om sy werk in verantwoordelikheid teenoor God te doen. Aangesien werk 'n roeping is, moet dit nie gereduseer word tot blote pligte ter wille van oorlewing nie, maar die sosiale en religieuse dimensie van werk moet gerespekteer word. Die reg tot arbeid maar ook die korrelate plig om die ekologie te bewaar deur volhoubaar te ontwikkel, is 'n wesentlike deel van menswaardigheid. Die skepping is God se skepping wat die mens in verantwoordelikheid teenoor God moet bestuur. Dit mag nie deur menslike eksploitasie, oorbevolking, besoedeling en onvolhoubare ontwikkeling vernietig word nie. Omgewingsbewaring behoort daarom in enige Christelike etiek 'n sentrale plek te beklee.

Die mens se beeldskap dui voorts daarop dat die mens medemenslik kan leef. In Genesis 1:27 word spesifiek vermeld dat God die mens as man en vrou skape. Hierdie uitdrukking dui daarop dat die mens 'n sosiale wese is wat binne gemeenskap leef (vgl. Dreyer 2000: 675). Intermenslike verkeer en medemenslike verhoudings vorm 'n wesentlike deel van menswees. Net soos wat man en vrou in 'n verhouding met mekaar kan leef, kan die mens ook in ander sosiale verhoudings tree (vgl. Berkouwer 1957:195, Barth 1960:228). Wanneer die mens daarvan weerhou word om deel te kan hê aan intermenslike verkeer, vrylik te kan kommunikeer, assosieer, homself uit te druk, voort te kan plant, familieverhoudings te hê, en lief te kan hê, word sy waardigheid aangetas (Vorster 2003:288).

Die mens se geskapenheid as sosiale wese veronderstel 'n reg tot vryheid en gelykheid. Die mens kan homself alleen binne sosiale verhoudings realiseer wanneer hy 'n bepaalde handelingsvryheid het wat die reg tot selfverwesenliking, assosiasie en uitdrukking insluit. Terselfdertyd het die mens die verantwoordelikheid om sy medemens se Godgegewe reg tot vryheid en selfverwesenliking te respekteer. Vry- 
heid is nooit ' $n$ doel op sigself nie, maar word altyd medebepaal deur die Wil van God en die belange van die medemens, sodat vrye verantwoordelikheid en verantwoordelike vryheid altyd saamhoort (vgl. Van Wyk 1987:36).

Omdat alle mense na die beeld van God geskape is, is alle mense gelykwaardig. Die uitspraak dat God die mens as man en vrou geskape het, veronderstel nie 'n hiërargie tussen mense nie, maar stel die gelykwaardigheid tussen mense omdat die mens, ondanks gedifferensieërde eienskappe, beeld van God is. Hierdie gedagte word in Genesis versterk deurdat die stelling dat die vrou uit die man geneem is, in Genesis 2:24 gebalanseer word met die opmerking dat die man die vrou sal "aanhang" (vgl. Dreyer 2000:676, 677). Man en vrou word verder afsonderlik as beeld van God voorgehou (Gen. 1:27 en 5:2). In Genesis 2:20-24 word die vrou die hulp, helper of gelyke van die man genoem. Daarmee word nie bedoel dat die vrou 'n minderwaardige wese teenoor die man is nie, maar wel 'n soortgelyke wese as die man waarmee hy medemenslike gemeenskap kan hê (vgl. Wentsel 1987:630). Verder word die kultuuropdrag aan alle mense gegee sonder onderskeid. Hieruit word dit duidelik dat God 'n gelyke status van waardigheid aan alle mense toeken. In hierdie gelykwaardigheid gaan dit nie oor 'n substansiële gelykheid in vermoëns en eienskappe nie, maar oor die erkenning van 'n gelyke status voor God en mekaar.

Die sondeval vernietig nie die mens se beeldskap van God nie, maar verdraai dit. Die mens se verhouding met God, sy medemens en die natuur word versteur. In plaas daarvan dat die mens God aanbid, probeer die mens soos God wees (Gen. 3:5). Die man begin heers oor die vrou (Gen. 3:16). Nie net geslagsverhoudings nie, maar alle menslike verhoudings word deur onderdrukking en uitbuiting gekenmerk (vgl. Genesis 6). Deur die sondeval verloor die mens sy vryheid en word hy slaaf van die sonde. Die gelykwaardigheid van alle mense wat na die beeld van God geskape is, word ontken deurdat mense hulle status voor God en mekaar nie meer eerbiedig nie. Selfs die mens en die skepping verkeer in konflik met mekaar. Die mens se roeping tot arbeid word 'n vloek wat deur swaarkry gekenmerk word (Gen. 3:16-19).

Die sondeval hef egter nie die mens se verhouding met God en sy roeping as verteenwoordiger van God op nie. Die sondeval tas alle 
dele van menswees aan, maar dit ontmenslik nie die mens nie (vgl. Calvyn Inst. 2.1.8). Aangesien die mens se beeldskap nie in sy eie inherente eienskappe te vinde is nie, maar 'n status is wat God aan die mens toeken, kan die mens se beeldskap nie vernietig word deur die sondeval nie. God handhaaf selfs na die sondeval die mens nog steeds as mens (vgl. Berkouwer 1957:197, 198). In Genesis 9:6 word die mens steeds ná die sondeval beeld van God genoem. Juis omdat God die mens se waardigheid wil handhaaf, verbied Hy doodslag. Die burgerlike owerheid word deur God ingestel om die waardigheid van mense te beskerm (vgl. Deut. 17:15). In Psalm 8 besing die psalmdiger, ondanks die sondeval, die feit dat die mens net minder as 'n hemelse wese gemaak is, en dat hy as God se verteenwoordiger oor die skepping heers. God hou verder sy verhouding met die mens in stand deur 'n verbond met die mens te sluit waarin Hy sy roeping aan die mens herhaal, eise stel, maar ook beloftes van herstel maak.

\subsection{Sosiale geregtigheid in die Ou Testament}

God se antwoord op die sonde is dat Hy sy skepping herskep. Die herskeppende werk van God bestaan daarin dat Hy die mens se beeldskap herstel, asook die aanvanklike Goddelike orde van reg. Sosiale en institusionele geregtigheid kom in die Ou Testament veral ter sprake wanneer die stamme צמשפט saamgebruik word. צדק sord gewoonlik in Afrikaans met "geregtigheid" vertaal, terwyl משפט met "reg" vertaal word (vgl. Eloff 1988:110). צדק is 'n wyer begrip as משפט "צרפ". צדק dui op die algemene beginsel van geregtigheid, terwyl משרפ konkrete norm is wat binne ' $n$ juridiese en institusionele verband gekonkretiseer moet word (vgl. Eloff 1988:121 en Weinfeld 1992:236). In beide begrippe gaan dit oor gehoorsaamheid aan 'n persoonlike reg omdat God dit voorskryf (Wessels 1992:83). Die profete uit die agste eeu v.C. het die agteruitgang van sosiale waardes en die onderdrukking van armes aan die afwesigheid van צדק en משפט toegeskryf (vgl. Gosai 1993:244).

In die Ou Testament word God self aangedui as die norm, bron en maatstaf van alle menslike geregtigheid (Eloff 1988:113). Omdat God die beliggaming van geregtigheid is, is sy wette ook regverdig (vgl. Ps. 119:7, Deut. 4:6). Sonder God se aktiwiteit kan die mens nie in 'n regte verhouding met God staan nie, maar sonder sy wilsopen- 
baring van wat geregtigheid is, kan die mens ook nie in 'n regverdige verhouding met sy medemens staan nie (Eloff 1988:113). Die mens kan alleen 'n צדיק wees as hy konformeer aan die norm wat deur God gestel word (Gosai 1993:51). God se regsprekende aktiwiteit word deur מששפט uitgedruk. משטפט is beide 'n eienskap en daad van God. Hy is die God van reg wat reg laat geskied (vgl. Eloff 1988:117). In Jeremia word regverdige optrede telkens verbind aan ware kennis van Jahwe, terwyl onregverdige optrede voorkom omdat die mens nie die regsorde van God ken nie. Herstel kan alleen plaasvind wanneer die mens Jahwe weer leer ken (Wessels 1992:86, 89, 90). Sosiale geregtigheid kry so 'n religieus-etiese dimensie wat duidelik onderskeibaar is van 'n humanistiese fundering van sosiale geregtigheid.

Die verbond is die raamwerk waarbinne die eis tot geregtigheid gekonkretiseer word. Op verskeie plekke in die Ou Testament word die verbondsverhouding tussen God en sy volk beskryf as 'n verhouding wat gekenmerk word deur geregtigheid (Gen. 18:19, Deut. 6:25, Hosea 2:18). Die verskillende elemente van die verbond soos verwagtings, verantwoordelikhede en eise is karakteristieke wat fundamenteel is vir die konsep van צדק (Gosai 1993:54, 69). Die regte van die verbondsvolk en die aard van die sosiale orde in Israel word in God se historiese daad van die bevryding van Israel uit die onderdrukking van Egipte begrond. Die motief van bevryding is daarom een van die mees sentrale indikatiewe vir sosiale geregtigheid in die Ou Testament. Vryheid is 'n konkrete realiteit wat God deur sy bevrydingsdade skep en wat die Israeliet in die hede as Godgegewe gawe kan geniet. Geregtigheid is alleen moontlik wanneer Israel die aard van sy nuwe vryheid verstaan (vgl. Braulik 1998:212). Die verlossing uit Egipte is verder die grond vir die fundamentele gelykheid tussen die Israeliete (vgl. Braulik 1998:212). Daarom roep God in die verbond sy volk as geheel op tot ' $n$ lewe van geregtigheid teenoor almal, in die besonder vir die armes, swakkes en vreemdelinge (vgl. Eks. 23:6, Ps. 94:15, Spreuke 12:5, Amos 5:1). Sosiale geregtigheid is spesifiek die taak van die koning wat as tussenganger tussen God en sy verbondsvolk optree. Hy is die tussenganger tussen God se משכמש משרק aan die een kant, en die mens se צמשפט an משק an die ander kant (Wessels 1992:83). Die regspraak moes menswaardigheid handhaaf deur die regte van weerloses te beskerm en geregtigheid in die regspraak, breë ekonomie, 
die hef van belastings en in algemene landsregering te handhaaf (vgl. Eloff 1988:174). In die Ou Testament kry sosiale geregtigheid egter ook ' $n$ universele dimensie. Soos wat die koning verantwoordelik is vir sosiale geregtigheid, so is God verantwoordelik vir reg tussen die nasies (vgl. Bosman 1995:226; vgl. ook Ps. 98:9). Die volk moet terselfdertyd die weg tot vrede vir alle nasies voorberei deur 'n eksemplariese gemeenskap van geregtigheid te wees.

Uit die bostaande word dit duidelik dat geregtigheid in die $\mathrm{Ou}$ Testament ten diepste ' $n$ begrip is wat in die Godsleer setel en te doen het met dade wat met God se wil ooreenstem.

Die Ou-Testamentiese wette bevat vier groepe wette wat verskillende aspekte van menswaardigheid beskerm. Aangesien hierdie voorskrifte gerig is op 'n antieke Oosterse samelewing, kan dit nie in hulle konkrete toepassing op 'n letterlike en a-historiese wyse as geldend vir 'n moderne samelewing voorgehou word nie. Tog gee die wette 'n prinsipieel-teologiese betekenis aan menswaardigheid wat wel relevant is vir vandag. Die eerste groep wette beskerm die reg op lewe. Lewe word eksplisiet in die sesde gebod beskerm (vgl. Eks. 20:13 en Deut. $5: 17)$. Die verbod op die neem van lewe word begrond in die feit dat God die Alleenbeskikker oor lewe is. Wanneer iemand gedood word, word die beeldskap van God in hom vernietig, en word God van sy eiendom ontneem (vgl. Num. 35:33, Gen. 9:5, 6, 2 Sam. 12:9-10). Verskeie ander wette beskerm lewe op 'n positiewe wyse. Enkele voorbeelde kan genoem word:

- Die lewe van 'n medemens mag nie in gevaar gestel word deur nalatige optrede nie (vgl. Lev. 19:6, Deut. 22:8, Eks. 22:28 en 29).

- 'n Man wat pas getroud is, mag nie saam met die leër optrek in oorlog nie. Hy moet toegelaat word om 'n nageslag te hê. So word die voortgang van lewe beskerm (Deut. 24:5).

- Wraakneming word verbied. Vaders mag nie oor die sondes van hulle kinders, of kinders oor die sondes van hulle vaders doodgemaak word nie, terwyl asielstede ook ingestel word om 'n onopsetlike moordenaar teen bloedwraak te beskerm (vgl. Deut. 19:113, 24:16).

- Die lewe van skuldenaars word beskerm deurdat die skuldeiser hom aan die lewe moet hou deur vir hom te sorg (Lev. 25:35). 
'n Tweede groep wette beskerm liggaamlike integriteit. Dit sluit in beskerming teen verkragting (Deut. 22:25), ontvoering met die oog daarop om iemand as 'n slaaf aan te hou (Eks. 21:16, Deut. 24:7), bloedskande (Lev. 20:11,12, 14), bestialiteit (Eks. 22:19, Lev. 20:1516), vloek en slaan van ouers (Eks. 21:15, Lev. 20:19), sodomie (Lev. 18:22, 20;13) en owerspel (Lev. 20:10, Deut. 22:21-24.

'n Derde groep wette beskerm die reg op 'n menswaardige bestaan. Die regverdigheid van die Israelitiese samelewing word deur God gemeet aan die welstand van die afhanklikes in die samelewing soos die slawe, armes, vreemdelinge, weduwees, en weeskinders. God is die Beskermer van die afhanklikes en daar sal aan hom verantwoording gedoen moet word oor die toestand van die afhanklikes (vgl. Hamilton 1992:139, 150). Verskeie wette het 'n menswaardige bestaan vir die swakkes verseker. Enkele voorbeelde kan ter illustrasie genoem word:

- Geen Israeliet kon permanent verslaaf word nie (Lev. 25:39-41, Eks. 21, Deut. 15).

- Vreemdelinge het dieselfde godsdienstige en juridiese regte as Israeliete geniet (vgl. Lev. 25:47, Deut. 28:43, Deut. 1:16).

- Die ekonomiese regte van die vreemdelinge, weeskinders, weduwees en armes is omvattend beskerm (vgl. Lev. 25:10, Deut. 15:9, 24: 15, 19-22 en 15:1 en 2).

'n Vierde groep wette het spesifiek die waardigheid van die groep beskerm. Israel is ' $n$ verbondsgemeenskap wat individueel en kollektief aan God behoort. Daarom word nie net individuele regte beskerm nie, maar die individu moet ook die kollektiewe belang van die verbondsgemeenskap dien. Die eis tot respek vir die waardigheid van die groep vloei voort uit die sin vir verbondsgemeenskap en respek vir mekaar as die beeld van God (vgl. Vriezen 1966:420). Respek vir die waardigheid van die groep bestaan daarin dat die ekologie beskerm moet word (vgl. Eks. 23:12, Lev. 25:4-8, Eks. 23:10), dat die godsdienstige instellings van die volk gerespekteer moet word (Deut. 13, 16:21, 18:9-14, Num. 28-30, Lev. 11-16), dat die regspraak regverdig moet wees (Lev. 19:15, Deut. 1:17, 16:19, 19:18 en 19, 25:3), dat die waardigheid van die familie as instelling van God gerespekteer moet word (vgl. Eks. 22:16-19), en dat die eiendom van ander gerespekteer moet word (vgl. Deut. 25:13-16). 
Uit die bogenoemde is dit duidelik dat menswaardigheid in die Ou-Testamentiese wette uit vier kernbeginsels bestaan, naamlik die reg op lewe, liggaamlike integriteit, 'n menswaardige materiële bestaan, en die beskerming van die waardigheid van die groep. Menswaardigheid kan alleen tot sy reg kom as sosiale geregtigheid geskied in ooreenstemming met God se wil.

\subsection{Versoening in Christus}

Soos in die Ou Testament word respek vir menswaardigheid in die Nuwe Testament begrond in die verlossingswerk van God. Deur sy kruisdood en opstanding breek Christus die mag van die sonde en dood oor die skepping. Hy kom vestig 'n nuwe bedeling van vryspraak en genade op aarde waarin die mens op grond van die plaasvervangende offer van Christus en sy volmaakte gehoorsaamheid aan die wet regverdig verklaar word voor God (vgl. Rom. 3:25, 5:9, 10). Deur sy versoeningswerk skep Christus nuwe moontlikhede vir die mensheid en herstel Hy die waardigheid van die mens as beeld van God.

Die Nuwe Testament toon Christus aan as die volmakkte beeld van God. In 2 Korintiërs 4:4 en 6 word Christus die $\epsilon i$ kìv тôे $\theta \in \mathrm{v}$

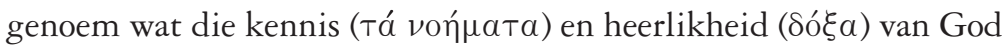
uitstraal. Christus se volmaakte beeldskap word deur Paulus in verband gebring met die semi-tegniese term $\delta$ ó $\xi a$ wat God se selfopenbaring in Christus uitdruk (vgl. Ramsey 1993:290). Uit Christus straal die heerlikheid van God self, sodat die heerlikheid van God in die woorde en handelinge van Christus aangevoel kan word (2 Kor. 4:6). Wie vir Christus sien, sien vir God (Joh. 1:14). In Kolossense 1:15 word Christus weer eens as die $\epsilon \dot{\epsilon} \kappa \hat{\nu} \nu$ Tov̂ $\theta \in \mathrm{ov}$ van die onsienlike God beskryf. Die bedoeling is duidelik dat Christus 'n sigbare manifestasie is van die onsienlike God.

Aangesien Christus die heerlikheid van God uitstraal word die mens opgeroep om gelykvormig ( $\sigma u ́ \mu \mu о \rho \phi o s)$ aan die beeld van Christus te word. In 2 Korintiërs 3:18 word die vernuwing van die mens se beeldskap toegeskryf aan die werking van die Heilige Gees. Die hernuwing van die beeldskap is 'n eskatologiese gawe van God aan die mens, wat nou reeds begin, en stelselmatig deur die Heilige Gees voltrek word (vgl. Vorster 2003:326). Omdat die herstelde beeldskap 'n gawe is, het geen mens enige reg tot selfroem nie en is alle gelo- 
wiges gelyk voor God (vgl. Gal. 3:28). In Efesiërs 4:24 en Kolossense 3:10 word 'n nadere invulling van die mens se herstelde beeldskap gegee. In Kolossense 3:10 word die herstelde beeldskap in verband gebring met kennis ('́Tí $\gamma \nu \omega \sigma \iota s)$. Volgens Louw \& Nida (1988, vol. 2:334) dui é $\pi i ́ \gamma \nu \omega \sigma$ เS op 'n regte kennis van God en 'n genoegsame verstaan van sy wil wat sigbaar word in intieme gemeenskap met God.

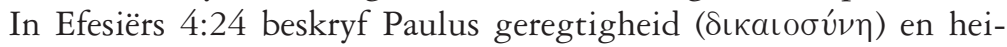

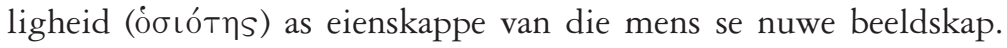
"Geregtigheid" dui op 'n nuwe lewe in ooreenstemming met God se wil en "heiligheid" dui op 'n innerlike ingesteldheid wat ooreenstem met God se wil (Louw \& Nida vol. 2:744, 745). Uit bogenoemde word dit dus duidelik dat kennis, geregtigheid en heiligheid wesentlik tot die herstelde beeldskap hoort. Al drie gawes het betrekking op die mens se verhouding met God. Kennis is 'n verstaan van God se wil, geregtigheid 'n nakoming van sy wil, en heiligheid 'n innerlike instemming met God se wil (vgl. Vorster 2003:327).

As die volmaakte beeld van God word Christus 'n model vir ware menswees wat nagevolg behoort te word. Die Griekse woorde wat in die Nuwe Testament vir die navolging van Christus gebruik word, is

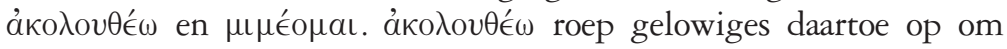
gemeenskap met Christus te hê deur 'n deelname aan die nalatenskap van Christus se verlossingswerk wat sigbaar word in gehoorsaamheid, selfverloëning en opoffering vir die nuwe bedeling van God (vgl.

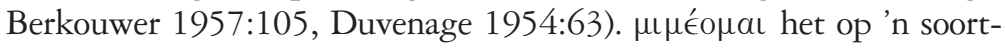
gelyke wyse te doen met 'n konkrete onderhouding van en gehoorsaamheid aan God se wil (Duvenage 1954:71). So word die bevryding wat Christus bring die grond van die nuwe mens se bestaan in waardigheid.

Hoe lyk navolging van Christus in die praktyk? In die Nuwe Testament word navolging van Christus telkens gerig op die naaste. Duvenage (1954:77) stel dit soos volg:

Die navolging van Christus omvat dade en konkrete eise, waarvan die mikpunt, doel en gestaltegewende prinsipe die naaste is.

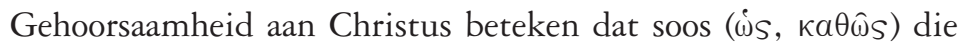
voorbeeld van Christus teenoor die naaste opgetree moet word. Dit veronderstel 'n lewe van liefde, diens, vergewensgesindheid, en nede- 
righeid teenoor die naaste (vgl. Fil. 2:5, Kol 3:13, Efes. 4:32, 5:2, Joh. 13:14, 15). In Matteus 5:48 word liefde ook teenoor die vyand as 'n vorm van navolging van Christus voorgehou. Die liefde kry so 'n universele dimensie.

Hieruit kan die gevolgtrekking gemaak word dat 'n ware navolging van Christus neerkom op 'n lewe waarin hoë respek vir die waardigheid van ander getoon word. Hierdie respek strek nie net tot die onmiddelike naaste nie, maar tot alle mense. Die kerk behoort daarom 'n paradigmatiese gemeenskap van versoening in die wêreld te wees (Moltmann 1984:32). Die versoening in Christus is die diepste rede waarom die Christen in die wêreld versoening met sy medemens moet najaag. Die Christen sal noodwendig versoening najaag op dieselfde wyse waarop Christus versoening na die wêreld gebring het deur die minste te wees en soms regte op te gee ter wille van die regte van ander. Sodoende word Christene agente vir hoop en getuies van God se toekoms wat wag (vgl. Moltmann 1984:32).

\subsection{Die koninkryk van God}

Die koninkryk van God is in drie opsigte belangrik vir die debat oor menswaardigheid. Eerstens beklemtoon die koninkryksbegrip die kosmologiese en soteriologiese dimensie van Christus se heerskappy. In die koms van sy koninkryk herstel God sy glorie op aarde, vernuwe Hy die mensheid en transformeer Hy sy skepping (vgl. Moltmann 1984:31). Christus se koningskap strek nie net oor die kerk nie, maar sy bevrydende werk het implikasies vir die hele kosmos (vgl. Kol. $1: 16)$. Sy verlossingswerk moet daarom nie net in 'n eng soteriologiese sin verstaan word nie, maar ook in 'n holistiese kosmologiese sin. Dit moet nie net eskatologies verstaan word nie, maar ook as 'n immanente realiteit wat politieke betekenis het.

Die koninkryk van God vorm die raamwerk waarbinne die gelowige geregtigheid moet najaag. Christus se kosmiese regering is 'n regering van transformering waarin $\mathrm{Hy}$ onreg wat deur die sonde teweeg gebring word, hervorm tot reg en so reg laat geskied aan die wil van die Vader (vgl. Du Toit 1991:441). In verskeie teksgedeeltes word na die verband tussen die koninkryk en geregtigheid verwys. In Kolossense 4:11 noem Paulus die gelowiges medewerkers van God se koninkryk, 
in Romeine 14:17 word die koninkryk van God 'n koninkryk van geregtigheid genoem en in die saligsprekinge word die soeke na geregtigheid verbind aan burgerskap van die koninkryk van God (Mat. 5:10). Die soeke na die geregtigheid van God se koninkryk vind plaas binne die kader van die liefde. Aangesien God liefde is, is die liefde die vernaamste instrument van God se geregtigheidshandelinge. Sonder liefde kan geen geregtigheid bestaan nie, terwyl ware liefde altyd 'n instrument van geregtigheid sal wees (vgl. Du Toit 1991:446). In die liefde gaan dit nie net oor verhoudings met die nabye naaste nie, maar oor 'n algemene menslikheid teenoor alle mense (vgl. Efes. 5:2, Rom. 12:1, Fil. 2:1-2). Die liefde bind individue tot 'n gemeenskap saam.

In die Evangelie van Lukas word baie klem gelê op die feit dat Christus vrede (shalom) na die aarde bring. Christene het daarom die taak om die volledige koms van die koninkryk op aarde te antisipeer deur hulleself vir vrede te beywer. Oorlog, eksploitasie onderdrukking, kriminaliteit, ensovoorts moet deur Christene beveg word. Die Christelike manier om vrede te bevorder, is deur die evangelie van liefde en geregtigheid te verkondig. Alleen waar liefde en geregtigheid in harmonie funksioneer, kan vrede bestaan.

Die koninkryksbegrip gee tweedens 'n missionêre dimensie aan die lewe van die Christen op aarde. Matteus begrond die sendingopdrag van die kerk daarin dat "alle mag in hemel en op aarde" aan Christus behoort. Daarmee word die koninkryk as 'n teenswoordige realiteit aangetoon wat alle aardse mag in die lig van Christus se koningsheerskappy relativeer. Die koninkryk van God het nie die kerk as rigpunt nie, maar eis die wêreld vir God op. Christene moet daarom getuies wees van die bevrydende werking van God in die geskiedenis deur hulleself te beywer vir die beginsels van God se koninkryk en die groter realisering van menswaardigheid deur respek vir die regte van armes, swakkes en benadeeldes te bevorder. Die Heilige Gees is die gawe van die koninkryk wat die gelowige toerus vir sy taak in die wêreld.

Die koninkryk van God bepaal derdens die eskatologiese bestemming van die mens. Die koninkryk is nie net 'n teenswoordige realiteit nie, maar ook 'n toekomstige realiteit. Die mens het daarom 'n reg op die toekoms (vgl. Moltmann 1984:17). Die regte van toekomstige geslagte moet beskerm word deur die ekologie te bewaar en volhou- 
baar te ontwikkel. Die Christen moet die messiaanse hoop wat die koms van die koninkryk bring, uitdra deur die koninkryk te antisipeer en te getuig van die betekenis van die koms van die koninkryk vir die waardigheid van die mens (vgl. Moltmann 1984:22). Moltmann (1984: 109) stel dit treffend:

Though this world is not yet the kingdom itself, it is the battleground and construction site for the kingdom, which comes on earth from God himself.

\section{KONKLUSIE OOR DIE BYBELSE SIENING VAN MENSWAARDIGHEID}

Menswaardigheid is in die Bybel nie 'n statiese begrip wat in inherente eienskappe van die mens gefundeer word nie. Dit is eerder 'n relasionele begrip wat dui op 'n status wat God aan die mens toeken. Die mens is waardig omdat God die mens as waardig behandel. Geen mens mag daarom ander mense se waardigheid van hulle ontneem nie, want dit kom neer op opstand teen God. Terselfdertyd is menswaardigheid 'n etiese kategorie wat voortdurend positief ingevul moet word deurdat die mens met die Godgegewe moontlikhede tot sy beskikking sy verantwoordelikhede teenoor God, sy naaste en die skepping nakom. Reg en plig is korrelate begrippe wat ten nouste aan mekaar verbonde is. Individu en gemeenskap staan in ' $n$ interafhanklike verhouding met mekaar omdat die individu altyd sy medemens se beeldskap van God moet respekteer. Die plig tot handhawing van menswaardigheid kry vorm in die liefde wat as instrument van geregtigheid optree. Liefde en geregtigheid is regulatiewe ideale in die lig waarvan menswaardigheid gekonkretiseer moet word.

\section{DIE CHRISTELIKE GELOOF EN DIE KLASSIEK-LIBERALE BESKOUING VAN MENSWAARDIGHEID}

Dit is onrealisties om te dink dat die Christelike geloof die moderne sekulêre kultuur in Suid-Afrika kan verchristelik. Dit is egter ook verkeerd om die bydrae wat die Christendom in Suid-Afrika kan maak, te onderskat. Christene kan nie van alle mense verwag om hulle siening 
oor die aard van menswaardigheid te deel nie. Tog het Christene die fundamentele reg om hulle siening oor menswaardigheid met ander te deel en so te help bydra tot die realisering van menseregte (vgl. Moltmann 1984:10). Die Christelike siening van menswaardigheid kan die menseregtedebat verryk sonder om noodwendig religieuse oortuigings op ander af te dwing. Venter (2000:12) wys tereg daarop dat dit onmoontlik is om binne 'n pluralistiese samelewing 'n monolitiese konsep van menswaardigheid te handhaaf.

In Suid-Afrika het Christene genoegsame vryheid en toegang tot politieke strukture om 'n bydrae te maak tot die realisering van menswaardigheid. Dit is egter belangrik dat die waardes wat Christene propageer nie omvattende leë konsepte moet wees nie, maar gekontekstualiseer moet kan word.

Die Grondwetlike Hof werk oorwegend met die klassieke liberale siening van menswaardigheid. Menswaardigheid setel in inherente eienskappe van die mens wat onvervreembaar is. So probeer die howe om 'n fundering aan menswaardigheid te gee wat nie gerelativeer kan word nie, en as 'n globale-aanvaarbare etiek gebruik kan word. Die klassiek-liberale fundering van menswaardigheid skep egter verskeie probleme:

- Dit berus op die optimistiese mensbeeld van die Verligting, liberalisme en utilitarisme. Na twee Wêreldoorloë kan 'n optimistiese mensbeskouing egter nie meer enige geloofwaardigheid hê nie. 'n Nuwe fundering van menswaardigheid is daarom nodig (vgl. Saladin 1981:29).

- As gevolg van 'n optimistiese mensbeskouing lei die klassiekeliberale beskouing maklik tot individualisme. Volgens die klassiekliberalisme setel die mens se regte in sy eie outonome natuur en nie in enige eksterne verhoudings nie. Die beoefening van die mens se regte is daarom nie gerig op eksterne maatstawwe nie, maar op die realisering van die self. Die gevolg is dat dit moeilik is om met behulp van die klassiek-liberale benadering 'n kultuur van morele verantwoordelikheid te skep (vgl. Vorster 2003:339). Die klassieke-liberale benadering lei tot 'n spanning tussen individuele en sosiale regte omdat nie alle individuele regte noodwendig goed vir die gemeenskaplike goeie is nie. So word pornografie 
in Westerse samelewing toegelaat ter wille van vryheid van uitdrukking, hoewel dit openbare sedelikheid ondermyn. Die gevolg van die onderbeklemtoning van verantwoordelikheid is morele deformasie. Veral in Westerse lande is familie-en sosiale netwerke vinnig besig om te verbrokkel omdat vryheid negatief gedefinieer word as 'n "vrywees van ander", in plaas van positief as "vry vir ander". In samelewings soos Duitsland en die VSA lei die beklemtoning van regte en onderbeklemtoning van sosiale verantwoordelikheid toenemend tot legalistiese samelewings waarin mense se aansprake op verskillende regte voortdurend gebalanseer moet word (vgl. Küng en Moltmann 1990:100).

- Die klassieke-liberale benadering is soms abstrak en toon 'n gebrek aan empiriese begronding wat dit moeilik mak om die konsep van menswaardigheid te konkretiseer omdat dit geen objektiewe inhoud het nie. Menswaardigheid kan byvoorbeeld empiriesgesproke nie in die redelike kapasiteit van die mens begrond word nie. Sou gestremde mense of klein kinders met 'n klein redelike kapasiteit dan minder regte hê as ander? Vryheid en gelykheid is empiries gesproke ook nie aangebore eienskappe nie. Sommige mense het van nature meer gawes of weens beter omstandighede meer vrye geleenthede as ander. Die abstrakte inhoud van menswaardigheid maak konkretisering in regspraak moeilik veral wanneer byvoorbeeld vasgestel moet word of 'n vorm van diskriminasie 'n persoon se fundamentele waardigheid aantas.

- Die howe probeer die waarde van menswaardigheid konkretiseer deur die Grondwet reaktief te interpreteer. Die probleem is: Vir hoe lank kan menswaardigheid net reaktief in terme van SuidAfrika se verlede geïnterpreteer word nie? 'n Visie vir die toekoms wat die verlede transendeer, moet ook geskep word.

'n Christelike perspektief kan in verskeie opsigte 'n alternatief op die klassieke liberale idee van menswaardigheid bied.

- Die Christelike geloof gee 'n eksterne normering aan regte. Regte is nie besittings nie, maar is verhoudings wat institusioneel gedefinieer word om sosiale geregtigheid te bevorder. 'n Reg dui op 'n aanspraak wat die individu het om sy struktuurmoontlikhede ter wille van die gemeenskaplike goeie uit te leef. 'n Reg is nie 
'n reg omdat die individu dit as 'n reg begeer nie. As 'n reg nie die gemeenskaplike goeie dien nie, kan dit nie as 'n geldige reg beskou word nie. In die omskrywing van regte moet dit gaan oor die basiese struktuurmoontlikhede van die mens en die minimum voorwaardes wat nodig is vir sosiale geregtigheid en die gemeenskaplike goeie. Die implikasie is dat individuele en sosiale regte ten nouste saamhang. Kompeterende regte kan makliker gebalanseer word as regte gerig is op die gemeenskaplike goeie en nie uitsluitlik op die eiebelang van die individu nie.

- Binne die Christelike geloof korreleer "reg" met "verantwoordelikheid". Die menseregtedebat word tans vir egoïstiese doeleindes misbruik deur 'n eensydige klem op reg en 'n onderbeklemtoning van verantwoordelikheid (vgl. De Villiers 2000:213). 'n Christelike fundering van menswaardigheid wat klem lê op roeping en verpligting en 'n positiewe inhoud gee aan begrippe soos vryheid kan help om individuele en sosiale belange te balanseer.

- Die klassiek-liberale tradisie verskraal die fundamentele waardigheid of kernidentiteit van die individu tot onbeweeglike eienskappe van die mens. In die Skrif dui menswaardigheid op die omvattende relasie tussen God, mens en natuur. Die reg van die mens om sy Godgegewe moontlikhede uit te leef, behoort tot die kern van die mens se identiteit. Menswaardigheid kry so 'n veel omvangryker betekenis.

- Menseregte kan misbruik word wanneer die totale samehang en onverdeelde aard van menseregte ontken word. Op internasionale vlak word die menseregteleer dikwels misbruik vir politieke doeleindes deurdat menseregtetaal gebruik word om sekere ideologiese belange ten koste van ander te regverdig (vgl. Moltmann 1984: 30). Dit is daarom noodsaaklik dat menseregte onverdeeld gehandhaaf moet word deur eensydige beklemtonings van sekere regte te balanseer met die bevordering van ander regte. So moet die erkenning van politieke regte gebalanseer word deur die erkenning van sosio-ekonomiese en omgewingsregte, en omgekeerd. 'n Eensydige klem op sekere regte kan lei tot die skending van ander. Die Christelike perspektief maak 'n onverdeelde handhawing van menseregte moontlik omdat dit menswaardigheid onlos- 
maaklik verbind aan die verhouding van die individu tot God, die menslike gemeenskap en die skepping.

- In die Christelike geloof speel geregtigheid, liefde, versoening en vrede 'n samebindende rol. Dit laat 'n gemeenskap in solidariteit funksioneer. Hierdie begrippe kan as regulatiewe ideale dien om 'n visie te formuleer vir die toekoms in die lig waarvan menswaardigheid gekonkretiseer kan word.

\section{GRONDWETLIKE REGSPRAAK EN DIE CHRISTELIKE GELOOF}

Die Suid-Afrikaanse grondwetlike regspraak behoort 'n verskeidenheid van filosofiese perspektiewe op die Grondwet in ag te neem. 'n Pluralistiese benadering tot menswaardigheid kan die universialiteit van menseregte beter dien as wat 'n onkritiese oorname van die Westerse klassieke verstaan sal doen. Omdat die Christelike geloof die grootste godsdiens in Suid-Afrika is, behoort die howe kennis te neem van ' $n$ Christelike siening van menswaardigheid. Drie belangrike voorwaardes sal egter geld. Ten eerste kan teokratiese ideale nie op 'n pluralistiese samelewing en 'n godsdienstige-neutrale staat afgedwing word nie. Tweedens moet die universele gerigtheid van 'n Handves van Regte in gedagte gehou word. Derdens kan nie alle aspekte van die Christelike siening van menswaardigheid op 'n juridiese relevante wyse gebruik word nie.

Die Christelike geloof kan moontlik die volgende bydraes maak tot grondwetlike regspraak:

- Dit kan die howe help om 'n meer omvattende betekenis aan menswaardigheid te gee, veral in gelykheidsregspraak waar vasgestel moet word of 'n spesifieke vorm van diskriminasie 'n persoon se fundamentele waardigheid aantas. Menswaardigheid is volgens die Christelike konsep in meer aspekte geleë as die eienskappe wat in artikel 9(3) omskryf word. Dit omvat ook die struktuurmoontlikhede waarmee die mens geskape is.

- Dit kan help om 'n meer positiewe inhoud aan die grondwaarde van vryheid te gee. In die Christelike vryheidsbegrip gaan dit nie net oor 'n "vryheid van ander" nie, maar veral oor 'n "vryheid vir 
ander". Die Christelike vryheidsbegrip omvat verder nie net burgerlike vryhede nie, maar lê veral klem op substantiewe vryhede soos die mens se reg op arbeid, behuising, gesondheidsorg sake wat binne die Suid-Afrikaanse konteks van groot belang is.

- Die Christelike konsep van menswaardigheid kan help om te bepaal wanneer 'n reg ingeperk moet word. In die Christelike tradisie word die reg van die individu en die gemeenskap as 'n korrelate verhouding gesien. ' $n$ Reg sou volgens die Christelike siening ingeperk kan word wanneer die reg nie verantwoordelikheid teenoor die gemeenskap dien nie.

- Christelike begrippe soos geregtigheid, liefde en vrede kan as regulatiewe ideale dien vir die bevordering van menswaardigheid.

\section{BIBLIOGRAFIE}

\section{BARTH K}

1960. Church Dogmatics III/II. Edinburgh: T\&T Clark.

BERKHOUWER G C

1957. De mens het beeld Gods. Kampen: Kok.

\section{BOSMAN J G}

1995. Geregtigheid in die boek Miga. 'n Tradisie-historiese ondersoek na die begrip משפט. Skrif en Kerk 16(2):219-232.

\section{BRAULIK G}

1998. Deuteronomy and human rights. Skrif en Kerk 19(2):207-229.

\section{BURGER W}

1998. Afrika-Renaissance: 'n Nuwe menswaardigheid? Aambeeld 26(2):39-42.

\section{CALVYN J}

1984. Institusie van die Christelike godsdiens 1559. Boek 1. Uit die Latyn vertaal deur H.W. Simpson. Potchefstroom: Calvyn Jubileumfonds.

1986. Institusie van die Christelike godsdiens 1559. Boek 2. Uit die Latyn vertaal deur H.W. Simpson. Potchefstroom: Calvyn Jubileumfonds. 
Chaskalson A

2000. Human dignity as a foundational value of our constitutional order. South African Journal of Human Rights 16(2):193-205.

\section{COHEN S}

2001. Can dignity guide South Africa's equality jurisprudence? SAHR 17(1):34-58.

\section{De Villiers E}

2000. Human rights and moral responsibility: their relationship in the present South African society. Nederduitse Teologiese Tydskrif 41(3 \& 4):212-224.

DE WAAL J 1998. Human dignity. In: J. de Waal, I. Currie \& G. Erasmus (eds.), The bill of rights handbook (Western Cape: Juta), pp. 175-182.

\section{DREYER Y}

2000. Vrou as beeld van God. Deel 1: 'n Historiese ondersoek. Hervormde Teologiese Studies 56(2\&3):672-693.

\section{Du ToIT D}

1988. Die mens en sy regte: geloof en praktyk in Suid-Afrika. Kaapstad: Zebra. 1991. 'n Christelike beskouing van mensregte. In die Skriflig 25(4):439-456.

\section{Du Plessis L M} 1997. Die inhoud, betekenis en enkele implikasies van die Handves van Regte in die Suid-Afrikaanse Grondwet. Politikon 24(1):5-37.

\section{DuVENHAGE S C W}

1954. Die navolging van Christus. Potchefstroom: Pro Rege.

\section{ELOFF T}

1988. Staatsowerheid en geregtigheid met besondere verwysing na rasseklassifikasie: 'n teologies-etiese studie. Ongepubliseerde Th.D-proefskrif. Potchefstroom: PU vir $\mathrm{CHO}$.

\section{GosaI H}

1993. Justice, righteousness and the social critique of the eight century prophets. Theology and religion. New York: Peter. Land Series 7.

\section{HAMILTON J M}

1992. Social justice and Deuteronomy: the case of Deuteronomy 15. Atlanta, Georg.: Scholars Press. Dissertation series 136.

\section{KÖNIG A}

2002. Ek glo die Bybel ondanks al die vrae. Vaste bakens in 'n tyd waarin die Bybel in gedrang is. Lux Verbi: Wellington.

\section{KROEZE I J}

2002. Doing things with values. II. The case of ubuntu. Stellenbosch Law Review 2:252-264. 


\section{KÜNG H \& MOLTMANN J}

1990. The ethics of world religions and human rights. London: SCM.

\section{LOUW J P \& NiDA E A}

1989. Greek English lexicon of the New Testament based on semantic domains. Volume 2. New York: United Bible Societies.

\section{MolTManN J}

1984. On human dignity. Political theology and ethics. Translated from the German by M. Douglas Meeks. London: SCM.

\section{NAUdÉ T}

1999 Cases and comments. The value of life. South African Journal of Human rights 15(4):541-562.

\section{NTOUBANDi Z F}

2000. Human dignity in the South African Constitution. Ongepubiseerde L. LM-skripsie. Potchefstroom: PU vir CHO.

\section{RAMSEY P}

1993. Basic Christian etbics. Louisvill, Ken.: John Knox Press.

\section{RYKE E H}

2000. Menswaardigheid: 'n verkenning van Biestek se siening. Koers 65(3):377-397.

\section{SALADIN P}

1981. Christianity and human rights. In: Eckehart Lorenz (ed.), How Christian are buman rights (LWF: Geneva), pp. 25-35.

\section{SCHOOLING H}

1999. The notion of dignity in South African equality jurisprudence. Responsa Meridiana:1-18.

\section{SUID-AFRIKA}

1996. Constitution of the Republic of South Africa as adopted by the Constitutional Assembly on 8 May 1996 and as amended on 11 October 1996. (B34B-96) (ISBN:0260-20716-7).

\section{VAN WYK J H}

1987. Etiek en menseregte. In die Skriflig 21(81):31-40.

\section{VENTER F}

2000. Human dignity as a constitutional value: a South African perspective. Ongepubliseerde artikel.

\section{VORSTER N}

2003. Die kerk en menseregte binne 'n regstaat. Potchefstroom: PSP.

\section{VRIEZEN T C}

1966. Hoofdlijnen der theologie van het Oude Testament. Wageningen: H. Veenman en Zonen. 


\section{WEINFELD M}

1992. Justice and righteousness. משדק משפט the expression of its meaning. In: H.G. Reventlow \& Y. Hofmann (eds.), Justice and righteousness: biblical themes and their influence (Sheffield: JSOT), pp. 228-246.

\section{WENTSEL B}

1987. God en mens verzoend: Godsleer, mensleer en zondeleer. Dogmatiek, deel 3a. Kampen: Kok.

\section{WESSELS W J}

1992. Sosiale geregtigheid: 'n Perspektief uit die Jeremiaboek. Skrif en Kerk 13(1):80-91.

\section{HOFSAKE}

Bernstein and Others $v$ Bester No and Others 1996 (4) BCLR 449 (CC).

Carmichele v Minister of Safety and Security and Another 2001(16) BCLR 995 (CC).

Christian Lawyers Association of South Africa and Others $v$ Minister of Health and Others 1998 (11) BCLR 1434 (T).

Curtis v Minister of Safety and Security 1996 (3) SA 617 (CC).

Dawood and Another, Shilabi and Another, Thomas and Another $v$ Minister of Home Affairs and Others 2000(8) BCLR 837 (CC).

Ferreira $v$ Levin No and Others and Vryenhoek and Others $v$ Powell and Others 1996 (1) BCLR 1(CC).

Minister of Health and Others $v$ Treatment Campaign and Others (1) 2002 (10) BCLR 1033 (CC).

Mohamed and Another $v$ President of the RSA and Others 2001(7) BCLR 685 (CC).

National Coalition for Gay and Lesbian Equality and Others v Minister of Home Affairs and Others 2000(1) BCLR 39 (CC)

President of the Republic of South Africa and Another v Hugo 1997 (6) BCLR 708 (CC).

Prince $v$ President of the Law Society of the Cape of Good Hope and Others 2002(3) BCLR 231 (CC).

Prinsloov Van der Linde and Another 1997 (6) BCLR 759 (CC).

State v Dodo 2001 95) BCLR 423 (CC).

State v Makwanyane and Another 1995(6) BCLR 665 (CC). 
Acta Theologica

2005:1

Trefwoorde

Menswaardigheid

Grondwet

Skrif

Fundamentele regte
Keywords

Human dignity

Constitusion

Scripture

Fundamental rights 